\title{
4: $68253212-68301377$
}

National Cancer Institute

\section{Source}

National Cancer Institute. 4:68253212-68301377. NCI Thesaurus. Code C41805.

Physical location of BRDG1_Gene 